\title{
Climate Change farm-level Adaptation Measures among Soybean Farmers in Benue state, Nigeria
}

\author{
Ikyoosu B. M, Ezihe J.A.C, Odoemenem I. U.
}

Department of Agricultural Economics, University of Agriculture Makurdi, Benue state. Nigeria

\begin{abstract}
This study analyses climate change farm-level adaptation measure among soybean farmers in Benue state, Nigeria. The study used multistage sampling technique and primary data were collected from 217 soybean farmers. Objective (i) was realized using descriptive statistics, viz. percentages and frequencies. Objective (ii) was achieved using stochastic frontier model. Objective (iii) made use of multivariate discreet choice model (MNL). Objective (v) was realized using Factor Analysis model (FA). Results of the multinomial logit analysis showed that Age positively influenced the use of crop diversification at 5\% significant. Household size had positive relationship with the choice of crop diversification as farm-level adaptation measures. Farm size had a negative effect on the choice of multiple crop varieties. The stochastic frontier analysis showed that farm size was highly significant at $1 \%$ level of probability among soybean farmers. The computed mean of technical efficiency estimate was 0.12 and 0.90. The technical inefficiency model showed that land fragmentation (i.e. multiple farm plots) is significant at 5\%, off farm employment is significant at $1 \%$, both organic and inorganic had 10\% significant technical inefficiency. The factor analysis revealed that the major constraints to climate change and farm-level adaptation measures among the soybean farmers were public, institutional and technological constraints; land, traditional beliefs and farm distance constraints; high cost of inputs, small scale production and knowledge of cropping or building resilience constraints; The study, therefore, recommends, inter alia, proactive regulatory land use systems that will make soybean farmers to participate in cooperative membership, have access to extension services to enhance their investment in climate change farm-level adaptation measures that has a long-term effect. More also, Government and non-governmental organizations should help the farmers in the area of provision and/ or facilitate the provision of input-based farm-level adaptation measure in the study area. Again, intensive use of already proven adaptation measures at farm-level by the farmers at their
\end{abstract}

present resource technology will make them to reduce technical inefficiencies in the study area.

Keywords- Climate change, Farm-level, Adaptation, Measures, Soybean Farmers, Benue state.

\section{INTRODUCTION}

Research on climate change adaptation has been conducted by the IPCC, UNFCCC, United Nation Environmental Programme (UNEP), and several climate scientists. There are different definitions of adaptation, (Pielke, 1998, IPCC, 2007, and Smith, 1993), Defined adaptation as the adjustment in ecological, social, or economic systems in response to actual or expected climatic stimuli and their effects or impacts (IPCC, 2001).

The importance placed on adaptation is reflected in Article 10 of the Kyoto protocol where it "commits parties to promote and facilitate adaptation and deploy adaptation technologies to address climate change". Also Paris (2015) UNFCCC adopted version of the agreement charged parties; especially developing countries to pursue and redouble efforts to limit the temperature increase to $1.5^{\circ} \mathrm{c}$. The $1.5^{\circ} \mathrm{c}$ goal will require zero emission sometime between 2030 and 2050. Appropriate adaptation can reduce the negative effect of climate change. The capacity to adapt to climate change depends on many non-climatic factors: level of economic development and investments, access to markets and insurance and political considerations (Lioubimsteva and Henebry, 2009).

Soybean, Glycine $\max$ (L Merr) the miracle seed is the world's most important oil seed legume which is produced in most part of middle belt of the country especially Benue state. Some of other states producing soybean in the country includes Kwara, Kogi, Oyo, Ondo, Osun, Nasarawa, Taraba, Niger, Bauchi, Kaduna. (Salunkhe ; Adsule, et.al., 1992). In 1986 Nigeria was the second largest producer of soybean in sub-Saharan Africa (SSA), with over 65,000 metric tons (MT) followed Zambia 36,000 tons. (Singh et.al., 1987). Presently Nigeria produces about 500,000 MT of soybean annually making it the largest producer of the crop on the African continent. Benue state is producing 
above 175,000 MT out of the total 500,000MT making it the highest producer of the crop in the country. Recent study has showed that due to changes in climate being experienced, soybean production in Benue state has dropped by $10 \%$ of total annual production in the state between 2006 to 2007 (Agada, 2014). Soybean is a versatile crop and one of the mandate crops in Benue state.

Nutritionally, the important of soybean in the diet is explicitly stated in the following areas: soybean is economical and effective in the control of diseases such as stroke, heart disease, cancer, ulcer, high blood pressure, diabetes and loss of body weight among people living with HIV/AIDS, etc due to it protein mineral content. However the rapid climatic changes and inadequate farm-level coping strategies is threatening the production and utilization of soybean in Benue state. Thus, the need to analyze climate change and farm-level adaptation measures among soybean farmers in Benue state.

1. describe the farm-level adaptation measures being practiced by soybean farmers in Benue state.

2. determine the effect of farm-level adaptation measures on farm output of soybean farmers.

3. assess the factors that are influencing the choice of farm-level adaptation measures by soybean farmers in Benue state.

4. identify the major constraints to climate change farm-level adaptation by soybean farmers in Benue state.

The following hypothesis were postulated and tested.

1. Farm-level adaptation measures have no significant effect on farm output of soybean farmers in the study area.

2. There are no significant factors influencing choice of farm-level adaptation measures by soybean farmers in the study area.

\section{METHODOLOGY}

\section{Research Design}

This study made use of public opinion survey to collect the needed data, well-structured questionnaires were used.
The Study Area

The study area was Benue state.

Geographically, Benue state is located in the middle belt of Nigeria with Makurdi as its capital and lies between latitude 8 and $10 \mathrm{~N}$ and between longitude 6 and $8 \mathrm{E}$, with a land mass of 6.595 million hectares (BNARDA 1998).

Benue state shares boundaries with Cameroun to the south, Nasarawa to the North, Taraba state to the East, Cross River to the South, Enugu and Kogi states to the South West and West respectively (Anonguku et.al., 2010). The state is also bordered on the North by $280 \mathrm{~km}$ River Benue, and is traversed by $202 \mathrm{~km}$ of River Katsina-Ala in the inland areas.

The state has a population of $4,253,641$. By sex distribution the state has a population of 2,144,043 male and 2,109,598 females, making it the ninth most populous state in the country with about $80 \%$ of its population involved in agriculture and produces, rice, benniseed and maize. Others include sweet potato, millet and wide range of other crops viz. sugar cane oil palm, mango, citrus, bananas etc. The state has two distinct seasons, rainy and dry seasons. The rainy season stretches from April-october and the dry season from November-March. Annual rainfall varies from $1250 \mathrm{~mm}$. the hot season comes in mid April with temperatures between $32^{\circ} \mathrm{C}$ and $38^{\circ} \mathrm{C}$.

Agriculturally, Benue state is segmented into three Agricultural zones of A, B and C. the major ethnic groups in the state include Tiv, Idoma, Igede, Etulo, Aakpa, Lukum, Hausa, Akwaya and Nyifon. Benue state has a Guinea savannah kind of vegetation characterized with scattered trees and coarse grasses. (BNARDA, 1998).

Administratively the state is divided into three zones namely, Eastern or A, Northern or B and Central or C zones by the Benue Agricultural and Rural Development Authority (BNARDA). The zonal headquarters of the three zones are Adikpo, Gboko and Otukpo respectively in that sequence. The state has a total land area of about 30,955 square kilometers and administratively it is divided into 23 Local Government Areas. 

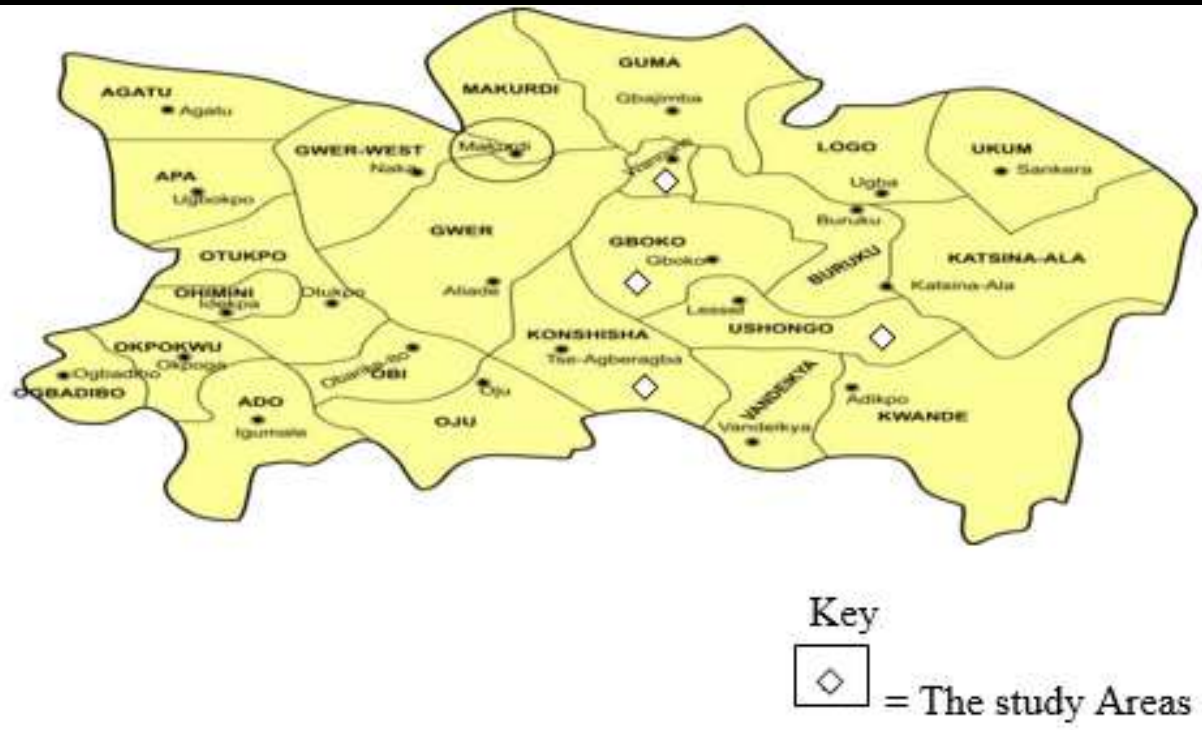

Fig. 1: Map of Benue State Showing the Location of the Study Areas.

\section{Source: www.Benuestatemap.com.}

\section{Population of the study.}

The population for the study comprises of all soybean farmers in Benue state.

The data for the study was collected from 217 randomly selected soybean farmers in the study area due to high population of soybean farmers and high level of soybean cultivation.

\section{Sample and Sampling Techniques.}

The major soybean producing agricultural zone was purposively selected for the study. Northern and NorthWest agricultural zones consisting of two (2) Local Government Areas were randomly selected from each zone. Three communities were randomly selected from each local government area and three soybean farming villages were also selected from each community.

Five (5) households were randomly selected from each farming village.

Table 1: Summary of the study location and sample chosen

\begin{tabular}{|c|c|c|c|c|}
\hline S/no & Zones & Communities & Sampling Frame & Respondents Sample $0.17 \%$ \\
\hline \multirow[t]{4}{*}{1} & Northern Ushongo & & - & - \\
\hline & & Utange & 133 & 20 \\
\hline & & Mbakuhwa & 122 & 18 \\
\hline & & Mbadede & 166 & 25 \\
\hline \multirow[t]{4}{*}{2} & Konshisha & & - & - \\
\hline & & Iwarnyan & 89 & 14 \\
\hline & & Mbamar & 78 & 12 \\
\hline & & Iwarev & 122 & 18 \\
\hline \multirow[t]{4}{*}{3} & North West Gboko & & - & - \\
\hline & & Mbadeda & 133 & 25 \\
\hline & & Mbanev & 122 & 18 \\
\hline & & Tse-kucha & 122 & 20 \\
\hline \multirow[t]{5}{*}{4} & Tarkaa & - & & - \\
\hline & & Mbanoughu & 56 & 10 \\
\hline & & Shitile & 78 & 15 \\
\hline & & Pipeline & 89 & 20 \\
\hline & 4 & 12 & 1320 & 217 \\
\hline
\end{tabular}

Source: field survey (2016) 
Instrument of Data Collection.

\section{Method of Data Collection.}

Data for this study was collected from primary source.

Primary data was collected through the use of a well structured questionnaire, copies of which were administered to the selected 217 soybean farmers in the study area.

Primary data was collected on the adaptive measures for mitigating the effect of climate change, factors influencing the choice of adaptation measures, constraints to climate change adaptation measures in the study area.

\section{Model Specification.}

The data for this study was both descriptive and inferential statistics.

Objective (i) was realized using descriptive statistics, viz. percentages and frequencies. Objective (ii) was achieved using stochastic frontier model. Objective (iii) made use of multivariate discreet choice model (MNL). Objective while objective (iv) was analyzed using Factor Analysis model (FA).

\section{Multivariate Discreet Choice Model.}

The Multinomial Logit (MNL) model for climate change adaptation choice specifies the following relationship between the probability of choosing option $A \mathrm{i}$ and the set of explanatory variables $\mathrm{X}$ as (Greene, 2003):

$\operatorname{Pr}(\mathrm{Yi}=\mathrm{j})=\frac{e \beta j X i j}{1+\sum_{m=0}^{6} e^{\beta m X i j}}, j=0,1,2,3, \ldots, 6$

Where $\beta_{\mathrm{j}}$ is a vector parameter that relates the socioeconomic, farm and institutional characteristics $X_{i}$ to the probability that $\mathrm{Y}_{\mathrm{i}}=\mathrm{j}$. Because the probabilities of the six (6) main climate change adaptation strategies must sum to one, a convenient normalization rule is to set one of the parameter vectors, say $\beta 0$, equal to zero $(\beta 0=0)$. The probabilities for the six (6) alternatives then become (Greene, 2000):

$\operatorname{Pj} \equiv \operatorname{Pr}(Y i=j)=\frac{e \beta i X i j}{1+\sum_{m=0}^{6} e^{\beta m X i j}}, j=1,2,3 \ldots \ldots 6$

$\mathrm{P}_{0} \equiv \operatorname{Pr}(\mathrm{Yi}=0)=\frac{1}{1+\sum_{m=1}^{6} e^{\beta m X i j}}$

The estimated parameters of a multinomial logit system are more difficult to interpret than those in a bivariate (or binomial) choice model. Insight into the effect that the explanatory variables have on the climate change adaptation strategies decision can be captured by examining the derivative of the probabilities with respect to the kth element of the vector of explanatory variables. These derivatives are defined as (Greene, 2000):

$\frac{\alpha \operatorname{Pr}(Y i=j)}{\alpha X i k}=\operatorname{Pj}\left[\beta j k-\sum_{m=0}^{6} \operatorname{Pr}(Y i=m) \beta j k\right] j=0,1, \ldots \ldots 6$; $k=1, \ldots, k$

Clearly, neither the sign nor the magnitude of the marginal effects need bear any relationship to the sign of coefficients.
The $\mathrm{Y}_{\mathrm{i}}$ is the probability of choosing a climate change adaptation strategy. The following are the main climate change adaptation strategies used among soybean farmers;

1. using different or multiple varieties of soybean

2. change in location of soybean farmlands/plots (i.e. land fragmentation/ land use planning)

3. change in timing of operations/ change in planting dates (i.e. multiple planting dates)

4. crop diversification (i.e. changes in crop mix)

5. diversification of source of household income to unrelated off-farm employment (off-farm employment opportunities)

6. Planting of cover crops (cover cropping).

$\mathrm{X}_{\mathrm{i}}=$ socio-economic, farm-specific and institutional variables.

Socio-economic variables that were used partly as independent variables include:

Household size $\left(\mathrm{X}_{1}\right)=$ Number of individuals in the household.

Age $\left(\mathrm{X}_{2}\right)=$ Age of household head in years.

Education level of farmer $\left(X_{3}\right)=$ number of years of schooling of household head.

Years of climate change awareness $\left(\mathrm{X}_{4}\right)=$ number of years of household head's awareness of climate change.

Marital status $\left(\mathrm{X}_{5}\right)=$ farmers marital status or his responsibility.

Gender $\left(\mathrm{X}_{6}\right)=$ sex category of household head (dummy1for male; 0 otherwise).

Farm-specific variables that were used partly as independent variables include:

Farm size $\left(\mathrm{X}_{7}\right)=$ measured in hectares.

Average distance from homestead to the farm $(\mathrm{s})\left(\mathrm{X}_{7}\right)=$ Average distance from homestead in kilometers.

Institutional variables that were used partly as independent variables include:

Access to extension services $\left(\mathrm{X}_{8}\right)=$ number of formal extension visit in the cropping season.

Membership of cooperation $\left(\mathrm{X}_{10}\right)=$ Number of membership of cooperative that the farmer belong to.

Access to credit facilities $\left(\mathrm{X}_{11}\right)=$ access to formal credit (dummy 1 for access to credit; 0 otherwise).

\section{Stochastic Frontier Models}

\section{Stochastic Frontier Production Function}

The data in this study was fitted into Cobb-Douglas and average production forms of stochastic frontier production function and the best form was selected through the use of generalized log-likelihood test after meeting the econometric requirements.

Cobb-Douglass production form: 
ln $Y_{\mathrm{i}}=\beta_{\mathrm{o}}+\Sigma \beta_{i} \ln \left(X_{i}\right)+\left(V_{i}-U_{i}\right)$

Where:

$\beta_{0}-\beta_{i}=$ parameters estimates.

$\Sigma$ is the sign of summation.

$\mathrm{Y}_{\mathrm{i}}=$ the value of output in naira,

$\mathrm{X}_{1}=$ the total labour used in soybean production in mandays;

$\mathrm{X}_{2}=$ the total land area (farm size) used in soybean

production in hectares;

$\mathrm{X}_{3}=$ the total quantity of fertilizer used in soybean production in kilogrammes;

$\mathrm{X}_{4}=$ the total value of other agrochemicals (i.e. pesticides and herbicides) used in soybean

Production in naira, and

$\mathrm{X}_{5}=$ the depreciated value of farm implements (i.e. hoes, cutlasses, watering can, etc.) in naira.

It was calculated using straight line method of calculating depreciation. That is, Depreciation is

\section{Purchasing cost of the asset - Salvage value \\ Life span of the asset in years}

The $\mathrm{V}_{\mathrm{i}} \mathrm{s}$ are random errors that are assumed to be independent and identically distributed as $\mathrm{N}$

$(0, \sigma \vee 2)$ random variables; and the $\mathrm{U}_{\mathrm{i}} \mathrm{s}$ are non-negative inefficiency effects that are assumed to be independently distributed among themselves and between the Vis such that $\mathrm{U}_{\mathrm{i}}$ is defined by the truncation of the $\mathrm{N}\left(\mathrm{U}_{\mathrm{i}}, \sigma\right)$ distribution. Where $\mathrm{U}_{\mathrm{i}}$ is defined by:

\section{Inefficiency Effects Model}

$\mathrm{U}_{\mathrm{i}}=\delta_{\mathrm{o}}+\sum_{i=1}^{\infty} \delta i Z j i$

$\mathrm{U}_{\mathrm{i}}=$ inefficiency effect; $\delta_{\mathrm{i}}=$ coefficients of climate change adaptation strategies and socioeconomic factors.

$\mathrm{Z}_{\mathrm{ji}}=$ climate change adaptation strategies and socioeconomic factors (i.e. hypothesized efficiency changing variables).

$\mathrm{Z}_{1}=$ land fragmentation (number of farm plots used for soybean production as a result of change in climate);

$\mathrm{Z}_{2}=$ off-farm employment (income from unrelated employment in naira in order to adapt to climate change);

$\mathrm{Z}_{3}=$ inorganic fertilizer (in $\mathrm{kg}, 0$ otherwise);

$\mathrm{Z}_{4}=$ organic fertilizer (in $\mathrm{kg}$ );

$\mathrm{Z}_{5}=$ tree planting date (number of trees per farm);

$\mathrm{Z}_{6}=$ multiple planting date (number of trees planted in a season);

$\mathrm{Z}_{7}=$ years of awareness of climate change, and

To choose the functional form that best describes the inefficiency effect, the following hypothesis will be tested;

$\mathrm{H}_{0}: \gamma=\delta_{0}=\delta_{1}=\ldots \delta_{7}=0$, this hypothesis specifies that the inefficiency effects are not present in the model. If this hypothesis is accepted, then the soybean farmers are fully efficient. Then, the data will be better analyzed using average production function rather the frontier function, which assumes the presence of inefficiency in soybean production.

Test of the above hypothesis will be obtained by using the generalized likelihood-ratio statistic, which is defined by;

$\lambda=-2 \ln \left[\mathrm{L}\left(\mathrm{H}_{0}\right) / \mathrm{L}\left(\mathrm{H}_{1}\right)\right]=-2 \ln \left[\mathrm{L}\left(\mathrm{H}_{\mathrm{o}}\right)-\mathrm{L}\left(\mathrm{H}_{\mathrm{i}}\right)\right]$

Where $\mathrm{L}\left(\mathrm{H}_{0}\right)$ is the value of the likelihood function for the average production function

(Model 1), in which the parameter restrictions specified by the null hypothesis, $\mathrm{H}_{0}$ are imposed;

and $\mathrm{L}\left(\mathrm{H}_{1}\right)$ is the value of the likelihood function for the general frontier model. If the null

hypothesis is true, then $\lambda$ has approximately a Chi-square (or a mixed square) distributed with degrees of freedom equal to the difference between the parameters under $\mathrm{H}_{1}$ and $\mathrm{H}_{0}$, respectively; that is the number of parameters excluded in the model.

\section{Factor Analysis Model.}

Principal component analysis model was used in achieving objective (vii), which is

Specified as:

$\mathrm{Y} 1=\mathrm{a} 11 \mathrm{X} 1+\mathrm{a} 12 \mathrm{X} 2+* * *+\mathrm{a} 1 \mathrm{nXn}$
$\mathrm{Y} 2=\mathrm{a} 21 \mathrm{X} 1+\mathrm{a} 22 \mathrm{X} 2+* * *+\mathrm{a} 2 \mathrm{nXn}$
$\mathrm{Y} 3=\mathrm{a} 31 \mathrm{X} 1+\mathrm{a} 32 \mathrm{X} 2+* * *+\mathrm{a} 3 \mathrm{nXn}$

$\begin{array}{ll}*= & * \\ *= & * \\ *= & * \\ \mathrm{Yn}=\text { an } 1 \mathrm{X} 1+\operatorname{an} 2 \mathrm{X} 2+* * *+\operatorname{annXn} & \end{array}$

Where:

Y1, Y2 ...Yn = observed variables/constraints of soybean farmers on adoption of climate change adaptation strategies. a1 - an $=$ factor loadings or correlation coefficients.

$\mathrm{X}_{1}, \mathrm{X}_{2}, \ldots \mathrm{Xn}=$ unobserved underlying factors constraining soybean farmers from adapting to climate change adaptation strategies were retained, the study selected factors with high factor loadings scores \pm 0.4 or greater.

Data Analysis Techniques.

Descriptive statistics was used to analyze the objectives in this study especially,

Objective (i) and (ii) were analyzed using Descriptive Statistics such as Frequency, and Percentage.

Objective (iii) was analyzed using stochastic frontier analysis.

Objective (iv) was analyzed using Multinomial Logit Model MNL.

Objective (v) was analyzed using Factor Analysis Technique. 
Hypotheses (i) was tested using F-test and hypothesis (ii) were tested using $\mathrm{t}$ test as embedded in stochastic frontier models and multinomial logit, respectively.

\section{RESULT AND DISCUSSION}

\subsection{Result and Discussions}

Table 1 shows the numbers of questionnaire administered, completed, and returned. The analysis of data shall be restricted to the 204 questionnaires collected from respondents.

Table.1: questionnaire administered and returned

\begin{tabular}{llll}
\hline S/no & Items & Respondents & Percentages \\
\hline 1 & Number & $\mathbf{2 1 7}$ & $\mathbf{1 0 0 \%}$ \\
2 & administered & $\mathbf{2 0 4}$ & $\mathbf{9 6 \%}$ \\
& Number & & \\
& returned & & \\
\hline
\end{tabular}

Source: Field questionnaire, (2016)

\subsection{Climate Change Adaptation Measures used by Soybean Farmers.}

About 53.9\% respondents used planting across slop as a crop management practice to adapt to climate change, multiple soybean varieties were used by about $50.5 \%$ of the respondents. About $51.0 \%$ respondents were using land fragmentation to cope with change in climate. Majority of $1.5 \%$ respondents were practicing fallow or alternative tillage system to cope with changing climate. Multiple planting dates were used by $77.0 \%$ respondents in the study area. About $36.8 \%$ respondents in the study area were involved in off farm employment to reduce the reduction in income cause by climate change. The respondents practicing cover cropping were about $12.3 \%$ to caution the effect of climate change on their farm. Majority of $93.6 \%$ respondents in the study area were applying inorganic fertilizer to cope with the reduction in output as a result of changes in climate. About $27.9 \%$ of the respondents were using organic fertilizer or manure to adapt to climate change. About $27.9 \%$ of the respondents were planting trees to adapt to climate change. About $12.3 \%$ respondents in the study area were practicing shading or sheltering as an adaptation measure on their farms, $52.5 \%$ of the respondents were changing farm size as an adaptation measure on their soybean farm.

Table.5: Distributions of Respondents based on the Farm-Level Adaptation Measures use by Soybean Farmers in Benue state.

\begin{tabular}{llll}
\hline S/No. Variables & Frequency & Percentage \\
\hline 1 & Planting Across Slop & 110 & 53.9 \\
2 & Multiple Soybean Varieties & 103 & 50.5 \\
3 & Land Fragmentation & 104 & 51.0 \\
4 & Fallow/Alternative Tillage & 3 & 1.5 \\
5 & Multiple Planting Date & 157 & 77.0 \\
6 & Irrigation Practice & - & - \\
7 & Crop diversification & 85 & 41.7 \\
8 & Off Farm Employment & 75 & 36.8 \\
9 & Cover Cropping & 25 & 12.3 \\
10 & Inorganic Fertilizer & 191 & 93.6 \\
11 & Organic Fertilizer & 56 & 27.5 \\
12 & Planting Trees & 57 & 27.9 \\
13 & Shading/ Sheltering & 25 & 12.3 \\
14 Change in Farm Size & 107 & 52.5 \\
\hline
\end{tabular}

\section{Source: Field Survey 2016}

Table.6: Descriptive statistics distribution of respondents by the number of Farm-Level Adaptation measure used by Soybean

Farmers.

\begin{tabular}{lll}
\hline Adaptation Number & Mean & Standard Deviation \\
\hline Multiple Soybean type Number & 1.09 & 1.126 \\
Land Fragmentation & 1.99 & 2.620 \\
Multiple Planting Date Number & 1.64 & 0.975 \\
\hline
\end{tabular}




\begin{tabular}{lll} 
Off Farm Income & 37424.02 & 83030.874 \\
Cover Cropping Number & 166 & 18.905 \\
Fertilizer Number in KG & 149.88 & 90.505 \\
Tree Planting Number & 26.82 & 68.216 \\
Change in Farm Size & 1.25 & 1.414 \\
\hline
\end{tabular}

Source: Field Survey 2016.

\subsection{Effects of Farm-Level Adaptation Measures on Farm Output of Soybean Farmers in Benue State Nigeria.}

This presents the results of the analysis of the farm-level adaptation measures that determine the influence of technical efficiency in soybean production in Benue state.

The explanatory variables (or factors) are important in this study because they have important policy implications. The following variable were hypothesized as farm-level adaptation measures and other farmers and farm specific variables, land fragmentation, (i.e. number of farm plots), off-farm income ( $\$$ ) inorganic fertilizer used, organic manure, tree planting (no of trees), multiple planting dates and years of awareness of climate change. The results of the inefficiency models of soybean farmer in Benue state, Nigeria as showed in the table below. The following variable land fragmentation, inorganic fertilizer use, organic manure and multiple planting date had significant positive relationship with technical inefficiency while off-farm employment, years of awareness of climate change had significant inverse relationship with the technical inefficiency.

The positive coefficients simply imply that the variables have the effect of decreasing the level of technical efficiency. Any increase in the value of such variables would lead to an increase in the level of technical inefficiency. The inverse relationship implies that any increase in the value of the variable would lead to an increase technical efficiency.

\subsection{Factors Influencing Technical Inefficiency are Discussed below.}

1. Land fragmentation: the result shows that the coefficient for land fragmentation is positive and significant at $5 \%$ level of probability for all the respondents. For the positive significant coefficient, if implies that an increase in land fragmentation tends to increase level of the technical efficiency (i.e. decrease technical inefficiency). This finding agrees with the findings of Obwona (2000, 2006) and nearly similar with the finding of Otitoju (2008) of small-scale soybean production in Benue state, Nigeria which found out that increase in the number of fragmented land decreased technical efficiency.

2. Off-farm income or employment: the estimated coefficient of off-farm employment is positive and significant at $1 \%$ level of probability for the respondents in the study area. The positive relationship implies that as offfarm employment or income increases, the level of technical inefficiency tend to increase (i.e decrease technical efficiency). The positive relationship suggests that increases in non-farm activities are accompanied by a reallocation of time away from farm-related activities such as adoption of new technologies, intensification of other adaptation measures and gathering of technical information that is vital for enhancing production efficiency. The finding agrees with the finding of Abdulai and Huffman (2000) in which inefficiency increases with involvement in off-farm employment.

3. Inorganic and organic fertilizer use: the result showed that the coefficient for inorganic and organic fertilizer use is positive and are significant at $10 \%$ level of probability. The positive relationship for both inorganic and organic fertilizer use implies that as inorganic and organic fertilizer use increases, the level of technical inefficiency tend to decrease.

Table.7: Maximum likelihood Estimates (MLE) of the Stochastic frontier Production Function for Soybean Farmers in Benue

\begin{tabular}{llll}
\hline Beta $(ß)$ & Variable & State. & t-ratio \\
\hline 0 & Constant & 6.79 & $8.93^{*}$ \\
1 & Farm size & 2.24 & $28.11^{*}$ \\
2 & Seed & -0.53 & -0.33 \\
3 & Fertilizer & -0.007 & -0.08 \\
\hline
\end{tabular}




$\begin{array}{llll}4 & \text { Herbicide } & 2.01 & 2.45^{* *} \\ 5 & \text { Labour } & -0.03 & -0.99 \\ 6 & \text { Depreciation } & -0.02 & -0.51 \\ & \text { Inefficiency Model } & & \\ \text { Delta } & & & \\ 0 & \text { Constant } & -0.22 & -0.24 \\ 1 & \text { Land Fragmentation(No of Plots) } & 2.01 & 2.36^{* *} \\ 2 & \text { Off-Farm Income( }(\text { ) } & 4.8557 & 2.69^{*} \\ 3 & \text { Inorganic Fertilizer(1,0) } & 1.19 & 1.38^{* * *} \\ 4 & \text { Organic Fertilizer(1,0) } & 6.65 & 1.38^{* * *} \\ 5 & \text { Tree Planting (No of Trees) } & -0.009 & -0.22 \\ 6 & \text { Multiple Planting Dates } & -0.99 & -0.02 \\ 7 & \text { Years of Awareness of Climate change } & -0.29 & -0.02 \\ & \text { Sigma Squared } \delta^{2} & 1.84 & 4.09^{*} \\ & \text { Gamma } \gamma & 4.20 & 2.19^{* *} \\ & \text { Log Likelihood Function } & & -0.316\end{array}$

\section{Source: field survey 2016.}

${ }^{*},{ }^{* *},{ }^{* * *}=$ t-ratio Significant at $1 \%, 5 \% \& 10 \%$ level respectively

\subsection{Technical Efficiency Estimates for Soybean Farmers in Benue State.}

The technical efficiency shows the ability of farmers to derive maximum output from the inputs used in soybean production. Given the results of the preferred models (Cobb-Douglas stochastic frontier models), the technical efficiency estimates are presented and discussed subsequently (Table 8 ).
The results show technical efficiency among the soybean farmers in the study area; the computed technical efficiency varies between 0.12 and 0.90 with a mean of 0.6975 . This result of the mean efficiency (0.6975) is closely similar to the finding of Otitoju (2008) on small-scale soybean farmers in Benue State, Nigeria.

Table.8: Distribution of Technical Efficiency Estimate for Soybean Farmers in Benue state.

\begin{tabular}{lll}
\hline Efficiency Index & Frequency & Percentage \\
\hline$<=30$ & 6 & 2.9 \\
$31-60$ & 32 & 15.7 \\
$61-90$ & 166 & 81.4 \\
Total & $\mathbf{2 0 4}$ & $\mathbf{1 0 0}$ \\
Minimum Efficiency & - & 0.12 \\
Maximum Efficiency & - & 0.90 \\
Mean Efficiency & - & 0.6975 \\
\hline
\end{tabular}

\section{Source: Field Survey 2016}

3.6. Factors that Influence the choice of farm-level adaptation measures by soybean farmers in Benue state. The estimate of the multinomial logit (MNL) model for this study was undertaken by normalizing one category, which is referred to as the reference category; in this analysis, the base category is fertilizer application.

The result of the multinomial logit (MNL) model indicate that different socio-economic factors like (Age, Education year, year of awareness of climate change, marital status, household size, gender) farm-specific variables (farm distance, farm size) and institutional variables (Extension visit, membership of cooperative, access credit) affect the farmer`s choice of the farm-level climate change adaptation measures in soybean production in Benue state, Nigeria.

The results of the parameter estimates (the estimated coefficient) from the multinomial logit (MNL) model are presented in the table. The likelihood ratio test as indicated 
by Chi-Square statistics were highly significant at $\left(82.39^{*}\right)$, suggesting the model has a strong explanatory power.

Age is significantly and positively correlated to the probability of choosing crop diversification to fertilizer application farm-level climate change adaptation measures in the study area. This implies that as age of increase, soybean farmers have a long planning horizon and are more likely to choose crop diversification as farm-level climate change adaptation measure to be able to cope with climate change than the older counterparts.

This result disagrees with the work of Hassan and Nhemachena (2008) which found that age is inversely related to the probability of choosing Mono crop-livestock under irrigation. This also disagrees with the discovery by Bayard et al., (2006) that the age of farmers has a negative influence on the adoption of rock walls as soil management practice in Fort-Jacques in Haiti and on adoption of ibST in Connecticut Dairy farm (Foltz and Chang, 2001). It is assumed that the younger the farmer the likelihood that he/she is to adapt measure that will reduce the negative effect of climate change is more.

A unit increase in the age of soybean farmers would probably decrease respondent choice of crop diversification to fertilizer application farm-level adaptation measures by 0.139 (1.99) in the study area.

The result showed that there is a positive relationship between household size and the probability of choosing crop diversification to fertilizer application as farm-level adaptation measures in the study area. This implies that, the bigger soybean families are, the better they are able to choose crop diversification than fertilizer application by 0.177(1.97) significance as farm-level climate change adaptation measures in the study area. This result disagrees with the finding of Birungi and Hassan (2010) which found out that household size is negatively related to the adoption of fallow as land management technology in Uganda.
Farm distance to the residents of the soybean farmers household is negatively related to the probability of choosing multiple crop varieties and crop diversification to fertilizer application as farm-level adaptation measures in the study area. It implies that the proximity of the farmers residents to the farm permit or gives farmers the opportunity to choose multiple crop varieties and crop diversification by $-0.176(-1.65)$ and $-0.219(-1.68) \quad 10 \%$ significance to fertilizer application as farm-level adaptation measures in the study area. This result disagrees with the study of Birungi and Hassan (2010) that found out that distance for plot to farmers residence had positive relationship with adopting fallow, inorganic fertilizer as land management practices in Uganda.

Farm size has negative relationship with the probability of choosing multiple crop varieties to fertilizer application as farm-level adaptation measures in the study area. This means that household that own more plots or large farm size have higher probability of choosing farm-level adaptation measures than their counterparts with smaller farm land. This also implies that large hectares of land or farm size can influence farmers' decision to choose and use farm-level measures that will probably reduce the effects of climate change.

This finding agrees with the study of Birungi and Hassan, (2010) that larger land increases the probability of investment in land management.

Marital status is negatively related to the probability of respondents choosing crop diversification to fertilizer application as farm-level adaptation measure in the study area. This means that marital status of respondents would more likely influence their decision in choosing crop diversification to fertilizer application by $-3.597(-2.34)$ at $5 \%$ significance as farm-level adaptation measure in the study area.

Table.9: Parameter Estimates of the Multinomial Logit (mnl) Analysis of the Factors that Influence the Choice of Farm-Level Adaptation Measures by Soybean Farmers in Benue state.

\begin{tabular}{lllllll}
\hline $\begin{array}{l}\text { Explanatory } \\
\text { Variables }\end{array}$ & $\begin{array}{l}\text { Coefficient(Z) } \\
\text { MLT CRP V }\end{array}$ & $\begin{array}{l}\text { Coefficient(Z) } \\
\text { LAND FRAG }\end{array}$ & $\begin{array}{l}\text { Coefficient }(Z) \\
\text { MLT PLT D }\end{array}$ & $\begin{array}{l}\text { Coefficient(Z) } \\
\text { CRP DIV }\end{array}$ & $\begin{array}{l}\text { Coefficient }(Z) \\
\text { OFF F EMP }\end{array}$ & $\begin{array}{l}\text { Coefficient(Z) } \\
\text { COVER CRP }\end{array}$ \\
\hline Age $(\mathrm{yrs})$ & $0.019(0.55)$ & $0.005(0.19)$ & $0.532(1.28)$ & $0.136(1.99)^{* * *}$ & $-0.075(-1.25)$ & $-16.411(-0.01)$ \\
Gender & $0.623(0.85)$ & $-0.454(0.93)$ & $-0.714(-0.87)$ & $-1.659(-1.56)$ & $-0.316(-0.39)$ & $91.332(0.01)$ \\
Edu year & $0.009(0.16)$ & $0.079(1.57)$ & $0.038(0.51)$ & $0.027(0.28)$ & $0.063(0.62)$ & $-7.269(-0.00)$ \\
Household & $-0.374(0.62)$ & $0.022(0.46)$ & $0.094(1.22)$ & $0.177(1.97)^{* * *}$ & $0.035(0.37)$ & $6.772(0.00)$ \\
size & & & & & \\
Farm distance & $-0.176(-$ & $-0.112(-1.38)$ & $-0.134(-1.05)$ & $-0.219(-$ & $-0.051(-0.41)$ & $-26.182(-0.00)$ \\
& $1.65)^{* * *}$ & & & $1.68)^{* * * *}$ & & \\
\hline
\end{tabular}




\begin{tabular}{|c|c|c|c|c|c|c|}
\hline $\begin{array}{l}\text { C/change } \\
\text { awareness }\end{array}$ & $0.002(0.04)$ & $0.037(0.90)$ & $0.021(0.36)$ & $-0.026(-0.27)$ & $0.095(1.14)$ & $19.370(0.02)$ \\
\hline $\begin{array}{l}\text { Extension } \\
\text { contact }\end{array}$ & $-24.961(-0.00)$ & $0.272(0.39)$ & $-0.592(-0.45)$ & $0.962(0.65)$ & $-24.888(-0.00)$ & $91.855(0.01)$ \\
\hline Access credit & $-0.220(-0.17)$ & $-25.674(-0.00)$ & $1.444(1.04)$ & $-25.976(-0.00)$ & $-25.548(-0.00)$ & $26.205(0.00)$ \\
\hline Farm size & $-0.395(-2.58)^{* * *}$ & $0.010(0.09)$ & $-0.148(-0.83)$ & $-0.182(-0.71)$ & $-0.327(-1.43)$ & $-25.616(0.00)$ \\
\hline Marital status & $-0.613(-0.95)$ & $-0.677(-1.37)$ & $-0.634(-0.69)$ & $-3.597(-2.34)^{* * *}$ & $0.514(0.56)$ & $83.132(0.01)$ \\
\hline $\begin{array}{l}\text { M/ship of } \\
\text { cooperative }\end{array}$ & $0.419(0.62)$ & $-0.438(-0.68)$ & $-25.522(-0.00)$ & $0.037(0.03)$ & $-25.066(-0.00)$ & $-27.521(-0.00)$ \\
\hline constant & $-0.815(-0.58)$ & $0.994(-0.99)$ & $-3.223(-2.01)$ & $-4.591(-2.19)^{* * *}$ & $-0.350(-0.16)$ & $241.854(0.01)$ \\
\hline Number of & & & 204 & & & \\
\hline \multicolumn{7}{|c|}{$\begin{array}{l}\text { LR Chi }^{2}=82.39 \\
\text { PROB }>\mathrm{Chi}^{2}=0.0838 \\
\text { PSEUDO R }{ }^{2}=13.85\end{array}$} \\
\hline
\end{tabular}

Source: field survey, 2016

Note: MLTCRPV= multiple crop varieties, LAND FRAG= land fragmentation, MLTPLTD $=$ multiple planting date, CRPDIV= crop diversification, OFFFEMP $=$ off farm employment. COVERCRP $=$ cover cropping.

$*$ = Significant at $10 \%,{ }^{* *}=$ significant at $5 \%,{ }^{* * *}=$ significant at $1 \%$.

Reference base: Fertilizer Application

\subsection{Constraints to Climate Change Adaptation by Soybean Farmers in Benue State.}

The constraints by the respondents (soybean farmers) limiting soybean farmers on climate change adaptation in Benue state.

Under factor 1 (Lack of access to weather information, public and private institutions and technological constraints) were; lack of access to weather forecast technologies (0.431), lack of or inadequate government policies to empower soybean farmers (0.513), lack of access to supporting institutional facilities (0.671), lack of access to and awareness about NGOs programmes on climate change adaptation(0.588) limited government irresponsiveness to climate change management $(0.644)$, poor information on early warning system $(0.468)$, poor access to climate change adaptation information (0.600) lack of / or inadequate extension programmes directed to meet the climate adaptation measures in soybean production (0.737) and poor agricultural extension delivery (0.554).

In the present information age, information problems could pose serious challenges to farmers' coping strategies as they may not be aware of recent developments regarding climate change adaptations and the necessary readjustments needed. The lack of adaptive capacity due to constraints on resources such as the lack of access to weather forecasts technologies and information creates serious gaps between the farmers and useful information that should help them in their farm work. Weather forecasts are supposed to guide farmers on climate variability so that they can make informed decisions and useful farm plans. However, the absence of this facility will undoubtedly make the farmers become ignorant of the weather and situations and hence become vulnerable to the impact of changes in the climate and weather. This result agrees with the findings of the study of Ozor et al. (2010) that identified lack of access to weather forecasts and government irresponsiveness to climate risk management as a major barrier to climate change adaptation among households in Southern Nigeria.

Under factor 2 (land, traditional beliefs, and farm distance constraints) the constraining variables or factors that loaded high were; poor access to and control of land

(0.756), high cost of farmland (0.731), inherited system of land ownership (0.679), traditional belief against adaptation (0.562), far distance of household to soybean farm to their homestead(0.502). Individual farmer in traditional and/ or rural societies and or communities do not usually have title to farmland but enjoy user rights, which could be withdrawn at any time by the custodian of the communal land. Benhin (2006) noted that farm size and land tenure status are some of the major determinants of speed of adoption of adaptation measures to climate change.

The variables or factors that loaded high under factor $\mathbf{3}$ (high cost of seed, fertilizer and other inputs, small-scale soybean production and knowledge of coping or to build resilience constraints) includes; high cost of improved soybean seed (-0.627), high cost of fertilizer and other 
inputs (0.537), small scale production of soybean farming household (0.496) and inadequate knowledge of how to cope or build resilience (0.767). Ozor et al., (2010) noted that high cost of farm input is a major constraint or barrier to climate change adaptation among farming households in southern Nigeria.

Table.10: Varimax Rotated Factors/ Variables Contraining Soybean Farmers on Climate Change Farm-Level Adaptation in Benue state, Nigeria.

\begin{tabular}{|c|c|c|c|}
\hline & & Compone & \\
\hline Constraints & Factor 1 & Factor 2 & Factor 3 \\
\hline 1. Lack of access to weather forecast technology & 0.431 & & \\
\hline $\begin{array}{l}\text { 2. Lack of or inadequate government policies to } \\
\text { empower soybean farmers }\end{array}$ & 0.513 & & \\
\hline 3. Lack of access to supporting institutional facilities & 0.671 & & \\
\hline $\begin{array}{l}\text { 4. Lack of access to and awareness about NGOs } \\
\text { programmes on climate change adaptation }\end{array}$ & 0.588 & & \\
\hline $\begin{array}{l}\text { 5. Limited government irresponsiveness to climate } \\
\text { change risk management }\end{array}$ & 0.644 & & \\
\hline 6. Poor information to early warning system & 0.468 & & \\
\hline $\begin{array}{l}\text { 7. Poor access to climate change adaptation measure } \\
\text { information }\end{array}$ & 0.600 & & \\
\hline $\begin{array}{l}\text { 8. Lack of or inadequate extension programme } \\
\text { directed to meet the climate change adaptation } \\
\text { measures in soybean production }\end{array}$ & 0.737 & & \\
\hline 9. Poor agricultural extension delivery & 0.554 & & \\
\hline 10. High cost of farm land & & 0.731 & \\
\hline 11. Poor access to and control of land & & 0.756 & \\
\hline 12. Inherited system of land ownership & & 0.679 & \\
\hline $\begin{array}{l}\text { 13. Traditional belief/ practice e.g. on the timing of } \\
\text { planting }\end{array}$ & & 0.562 & \\
\hline $\begin{array}{l}\text { 14. Far distance of household to soybean farms to their } \\
\text { homesteads }\end{array}$ & & 0.502 & \\
\hline 15. High cost of improved soybean seed & & & -0.627 \\
\hline 16. High cost of fertilizer and other input & & & -0.537 \\
\hline $\begin{array}{l}\text { 17. Some scale production of soybean farming } \\
\text { household }\end{array}$ & & & 0.496 \\
\hline $\begin{array}{l}\text { 18. Inadequate knowledge of how to cope or build } \\
\text { resilience }\end{array}$ & & & 0.767 \\
\hline 19. Non availability of farm labour & & 0.574 & 0.460 \\
\hline
\end{tabular}

*Factor 1 = Public, institutional and technological constraints, Factor 2 = Land, traditional belief and farm distance constraints, Factor 3 = high cost of inputs, small scale production and knowledge of copping or to build resilience constraints.

**Constraints that loaded under more than one factor.

Note: Factor loading of /0.40/ is used at 10\% overlapping variance variables with factors loadings of less than /0.40/ not reported.

Source: computed from field data, 2016.

\section{TEST FOR HYPOTHESES}

H1. The significance of the Gamma $(\gamma)$ parameter at $5 \%$ level of significant rejects the null hypothesis that farmlevel adaptation measures have no significant effect on the farm output of soybean farmers due to the difference in their technical inefficiency effects were present and makes significant contribution to the farm output of soybean farmers.

H2. Result of the chi-square $\left(\chi^{2}\right)$ at $10 \%$ level of significant means the null hypothesis that there are no significant factors influencing choice of farm-level adaptation 
measures by soybean farmers in the study area is hereby rejected.

\section{CONCLUSION AND RECOMMENDATIONS 4.1 CONCLUSION}

Rural farmers' inability to access information regarding change in climate is known to be a big challenge. With the use of different climate change adaptation strategies, the farmers are still underutilizing their present resources and this make them to be both technically inefficient. Right combination of different farm-level adaptation measures rather than using one of these measures through their wealth of experience and making judicious use of their resources at the present technology level will make them to be more efficient.

\subsection{RECOMMENDATIONS}

There is need for putting in place policies and programmes that will make the soybean farmers to be proactive in the use of resources and at the same time adapting to climate change. Particularly the following recommendations are proffered:

1. There is a need to make the soybean farmers participate in programmes that address adaptation policies in the country;

2. For soybean farmers to be more efficient technically, government and non-governmental organizations should help them in the provision of input-based farm-level adaptation measures (e.g. multiple crop varieties) so that their production can be enhanced in the face of changing climate;

3. The extension programme aspect of climate change adaptation measures policy in Benue state should focus much more on the bottom-up participatory approach so that the indigenous and the emerging adaptation measures and technologies can be focused in the various soybean producing zones in the state;

4. Government should focus on provision of functional credit facilities to help the soybean farmers in the area of climate change adaptation especially the input based ones and/or government should make the financial environment conducive for private players to act because government cannot do everything; and Institutional reforms or innovation that can make soybean farmers to relate socially with their fellow farmers especially in the same area or vicinity should be encouraged, since farmer-to-farmer extension paradigm can promote innovation faster than other form of extension methods.

\section{REFERENCES}

[1] Archer, E.R.M. 2007. Vulnerable peoples and places. In Ecosystems and Human Well-being:Current state and trends: findings of the Condition and Trends Working Group, ed. Hassan, Scholes and Ash. USA: The Millennium Ecosystem assessment series 1.

[2] Baethgen, W.E., H. Meinke, and A. Gimene. 2003. Adaptation of agricultural production systems to climate variability and climate change: lessons learned and proposed research approach. Paper presented at Climate Adaptation.net conference "Insights and Tools for Adaptation: Learning from Climate Variability," 18-20 November, 2003, Washington, DC.

[3] Bayard, B., Jolly, C. M. \& Shannon, D. A. (2006). The adoption and management of soil Conservation practices in Haiti: the case of rock walls. Agricultural Economics Review, 7(2), 28- 39.

[4] Berkes, F. and Jolly D. 2001. Adapting to climate change: socio ecological resilience in a Canadian Western Arctic community. Conserv. Ecol 5(2): 18. Available online at: http://www.ecologyandsociety.org/vol5/iss2/art18/

[5] Benhin, J.K.A. (2006). Climate change and South African agriculture: impacts and adaptation options (CEEPA Discussion Paper No. 21). Pretoria, South Africa: University of Pretoria, Centre for Environmental Economics and Policy in Africa.

[6] Birungi, P. \& Hassan, R. (2010). Poverty, property rights and land management in Uganda.African Journal of Agricultural and Resource Economics, 4(1), 48-69.

[7] Bradshaw, B., Dolan H. and Smith B., 2004. Farmlevel adaptation to climatic variability and change. Crop diversification in the Canadian prairies. Climate change 67: 119 - 141 .

[8] Deressa, T., Hassan R. M., Alemu T., Yesuf M. and Ringler C., 2008. Analyzing the determinants of farmers' choice of adaptation methods and perceptions of climate change in the Nile Basin of Ethiopia. IFPRI Discussion Paper 00798.

[9] Dinar, A, Mendelson R, Evenson R, Parikh J, Sanghi A, Kumar K, McKinsey J, Dornbos, D.L., Jr., and R.E.Mullen. (1991). Influence of stress during soybean seed fill on seed weight, germination, and seedling growth rate. Journal of Plant Science, 71: 373-383.

[10]Eid HM, EL-Marsafawy SM. Adaptation to climate change in Egyptian agriculture and water resources. 3rd International symposium on sustainable 
Agrolbrahim et al.; AJAEES, 10(1): 1-6, 2016; Article no.AJAEES.218866 enviromental systems: New technologies and applications (AGRON 2002). Held on 26 -29 October, Egypt; 2002.

[11] Hassan, R. \& Nhemachena, C. (2008). Determinants of African farmers' strategies for adapting to climate change: Multinomial choice analysis. African Journal of Agricultural and Resource Economics, 2(1), 83104.

[12] IFPRI (2009): Climate change: Impact on Agriculture and cost of adaptation. http://www.ifpri.org/site default/files/publications/pr21.pdf

[13] IISD (International Institute for Sustainable Development). $2006 . \quad$ Understanding adaptation to climate change In developing countries. http://www.iisd.org. Accessed November 20, 2006.

[14] IPCC (Intergovernmental Panel on Climate change) 2007. Climate change: The scientific basis. http://www.ipcc.ch/

[15]IPCC. (2001). Climate Change 2001: Impacts, Adaptation and Vulnerability. In J. J. McCarthy, O. F. Canziani, N.

[16] Maddison, D., 2006. The perception of and adaptation to climate change in Africa CEEPA. Discussion paper No. 10. Centre for Environmental Economics and Policy in Africa. Pretoria, South Africa: University of Pretoria.

[17] Nhemachena, C. and Hassan R., 2007. Micro-level analysis of farmers' adaptation to climate change in Southern Africa. IFPRI Discussion Paper No. 00714.

[18] Nigerian Environmental Study Team (NEST), 2004. Regional climate modelling and climate scenarios development in support of Vulnerability and adaptation studies: Outcome of regional climate modeling efforts over Nigeria, NEST, Ibadan, Nigeria.

[19] Smit, B., Burton B., Klein R. J. T. and Wandel J., 2000. An Anatomy of adaptation to climate change and variability. Climatic Change, 45: 223 - 251.

[20] Lioubimsteve and Henebry, 2009. Vulnerability to climate change, the pathways to adaptation.

[21] Pieke (1998). Rethinking the role of adaptation in climate change policy. University of Colorado-538, Global environmental change 8(2), 159- 170, 1998.

[22] Benhin (2006) challenges faced by Cocoyam farmers in adapting to climate change in Southern Nigeria.

[23] Benhin J.K.A. (2006). Climate change and South African agriculture impacts and adaptation options CEEPA discussion paper NO: 21 centre for environmental Economics and policy in Africa, University of Pretoria. Pretoria.

[24] Abdulai, A. and Huffman, W. (2000). Structural Adjustment and economic efficiency of rice farmers in Northern Ghana; Journal of economic development and cultural change 48(3), 503-520.

[25] Foltz J. D. Chang H. H. (2002) the adaption of profitability of rbST on commercial dairy farm America Journal of Agricultural Economics, 84(4): 1021-1032.

[26] Salunkhe and Adsule; 1992. World oilseeds, Hard cover that can be search along internet debil. Idiota.ha/world oilseed.

[27] Apata, T.G., Samuel K. D. and Adeola A. O., 2008. Analysis of climate change perception and adaptation among arable food crop farmers in South Western Nigeria. Contributed Paper prepared for presentation at the International Association of Agricultural Economists' 2009 Conference, Beijing, China, August 16-22, 2009.

[28] Dinar, A, Mendelson R, Evenson R, Parikh J, Sanghi A, Kumar K, McKinsey J, Dornbos, D.L., Jr., and R.E.Mullen. (1991). Influence of stress during soybean seed fill on seed weight, germination, and seedling growth rate. Journal of Plant Science, 71: 373-383.

[29] Maddison, D., 2006. The perception of and adaptation to climate change in Africa CEEPA. Discussion paper No. 10. Centre for Environmental Economics and Policy in Africa. Pretoria, South Africa: University of Pretoria.

[30] Nhemachena, C. and Hassan R., 2007. Micro-level analysis of farmers' adaptation to climate change in Southern Africa. IFPRI Discussion Paper No. 00714.

[31] Nwaru and Onuaha 2010., The choice of Climate change Adaptation Strategies among food crop farmers in Southwest Nigeria. 3-15th annual national conference of Nigeria association of Agricultural Economics (NAAS) Bayelsa state, 2014. At Niger Delta University Wilberforce island.

[32] Ozor 2010. Implementating climate change Adaptation in cities.

[33] Hassan, R. \& Nhemachena, C. (2008). Determinants of African farmers' strategies for adapting to climate change: Multinomial choice analysis. African Journal of Agricultural and Resource Economics, 2(1), 83104. 